DOI: $10.15193 / \mathrm{ZNTJ} / 2018 / 116 / 250$

\title{
MARTIN KRÁL, MAREK ŠNIRC, BOHUSLAVA TREMLOVÁ \\ DIFFERENCES BETWEEN TECHNOLOGICAL AND TEXTURAL PARAMETERS OF MEAT FROM FARMED AND WILDLIFE RED DEER (CERVUS ELAPHUS) DETERMINED BY PCA METHOD
}

\begin{abstract}
S u m m a r y
Recently an upward trend has been reported in the consumption of wild meat, especially of the deer meat, for its nutritional value and specific taste. Chemical, technological and textural properties of meat are its basic quality indicators. Consumer preferences are strongly influenced by thermal treatment techniques of meat affecting its tastiness and the latter one alters with changes in the chemical and textural properties of meat.

The objective of the research study was to describe the quality of red deer (Cervus elaphus) meat and the differences between technological and textural parameters of meat from farmed and wildlife animals. Samples were collected from a Musculus semimembranosus muscle. In the analysis a method of principal components (PCA) was applied. The first seven principal components explained (described) more than $90 \%$ of the total variance of all the parameters studied, however the first three principal components described over $62 \%$ of the total variance of the parameters analyzed. In the case of the first principal component, the most significant variables thereof were: chewiness, springiness and cohesiveness of the fried samples, water bath cooking loss, content of fat and springiness of the cooked samples. The statistically significant differences $(\mathrm{p}<0.05)$ were found in the contents of water, protein and fat. The analysis of the texture profile showed significant differences $(\mathrm{p}<0.05)$ in the following parameters: springiness of the samples cooked in water bath, hardness and cohesiveness of the roasted samples, and springiness and chewiness of the fried samples. Based on the results of the analysis performed it was concluded that the value of $\mathrm{pH}$ as well as the chemical, technological and textural properties could provide useful information that make it possible to determine the origin of meat (farmed animals vs. wildlife animals).
\end{abstract}

Key words: Musculus semimembranosus, red deer, meat, thermal treatment techniques, quality, method of principal components (PCA)

PhD Ing. M. Král, Doc. MVDr. B. Tremlová, Department of Plant Origin Foodstuffs Hygiene and Technology, Faculty of Veterinary Hygiene and Ecology, University of Veterinary and Pharmaceutical Sciences Brno, Palackého tř. 1946/1, 61242 Brno, Czech Republic, PhD Ing. M. Šnirc, Department of Chemistry, Faculty of Biotechnology and Food Sciences, Slovak University of Agriculture in Nitra, tr. A. Hlinku 2, 94976 Nitra, Slovakia.Contact: martinxkral@gmail.com 


\section{Introduction}

Among consumers there is a growing interest in some characteristics of meat itself and also in the production system of meat or meat products. Above all else, meat is to be safe and without artificial additives added into the animal diet or into the product. Furthermore, consumers are increasingly concerned about the animal welfare and environmental aspects of animal production systems [25]. Other important qualitative factors of meat are its technological and textural attributes. Sensory and technological attributes of the final meat product depend on the quality of raw material and this depends on the animal species and the quality of fat [9].

Venison is attractive to consumers on account of several features: tenderness, low content of fat, favourable fat composition and high levels of minerals [12]. It is also characterized by a unique quality owing to the specific animal behaviour that results in different histochemical and structural properties of animal muscles [30]. Many researchers have reported the effects of age, gender, feed type (pasture vs. grain), region, production system and evisceration on the composition of meat from red deer, fallow deer, roe deer and reindeer. Deer farming has been proved to be a low input system [25] and in many markets the meat from farmed red deer is perceived as a high-value meat because of a number of such characteristics as a low content of fat and a high content of iron [8]. For grazing animals pasture is generally a sole source of feed with simple supplements added under certain conditions and/or for the purpose of improving animal performance [25]. Among other things, the findings by Wiklund et al. [28, 29] showed that the sensory panel could distinguish between animals fed grain-based pellets and those grazed on natural pastures. In their previous study, Šnirc et al. [22] reported the variances with reference to the Musculus longissimus thoracis et. lumborum. The present research study focuses on Musculus semimembranosus as well as on the quality of meat from farmed and wildlife red deer. Also the differences are described using a principal component analysis (PCA), and the technological and textural parameters are visualized.

\section{Material and methods}

\section{Animals}

The samples of Musculus semimembranosus were collected from 8 wildlife and 8 farmed red deer (Cervus elaphus). The weight of the wildlife animals was $78 \pm 3 \mathrm{~kg}$, their age was $<1.5$ year, their pastures were located in the central-western part of Slovakia. The weight of the farmed animals was $80 \pm 2 \mathrm{~kg}$, their age was $<1.5$ year, and the deer farm was in the south-western part of Slovakia. The deer and the carcasses were handled in compliance with the Regulation (EC) No. 854/2004 of the European Parliament and of the Council [21] as described in the study by Šnirc et al. [22]. 
Cooking procedures

The $2 \mathrm{~cm}$ thick meat samples were cooked and the following three cooking methods were applied:

1) water bath - the samples in a plastic bag were immersed in a water bath at $75^{\circ} \mathrm{C}$ for $45 \mathrm{~min}$, iced for $15 \mathrm{~min}$, and chilled at $4{ }^{\circ} \mathrm{C}$ for $45 \mathrm{~min}$;

2) convection oven - the samples in an aluminium foil were roasted at $190{ }^{\circ} \mathrm{C}$ to $70{ }^{\circ} \mathrm{C}$ of the internal temperature of the sample;

3) pan - every sample was fried using $20 \mathrm{~g}$ of a vegetable frying fat (Planta, Czech Republic) to the internal temperature of $\left[{ }^{\circ} \mathrm{C}\right]: 60,70,80$; the cooking loss was determined.

\section{Measurement}

The $\mathrm{pH}$ value of the muscle was measured $48 \mathrm{~h}$ after slaughter with a Gryf 259 pH-meter (Gryf HB, Czech Republic). A filter-press method was applied to assess the water holding capacity (WHC). The samples of $500 \pm 20 \mathrm{mg}$ were put under a pressure of $10 \mathrm{~kg}$ for $5 \mathrm{~min}$ [10]. A muscle sample ( $35 \pm 5 \mathrm{~g})$ was suspended in a plastic bag at 1 $\div 3{ }^{\circ} \mathrm{C}$ for $24 \mathrm{~h}$ and the liquid collected in the bag was weighed and expressed as a drip loss (DL) [13].

The instrumental measurements were performed and the percentage cooking loss was determined after the final cooking temperature reached $75{ }^{\circ} \mathrm{C}$ (water bath), $70{ }^{\circ} \mathrm{C}$ (roasting in the oven) and $80^{\circ} \mathrm{C}$ (frying) and all the samples were cooled down to have an internal temperature of $21^{\circ} \mathrm{C}$.

Water, protein, fat and ash were analysed according to AOAC methods [2]. The shear force and the Instrumental Texture Profile were determined using a TA.XT and a Texture Analyser (Stable Micro Systems, UK). The shear force was measured using a Volodkevich bite jaws probe and the samples were cut to $50 \%$ across the sample fibres.

The Instrumental Texture Profile (hardness, springiness, cohesiveness and chewiness) was measured by a double compression cycle test according to Szczesniak [23]. An aluminium cylinder probe of $38 \mathrm{~mm}$ diameter compressed the samples $(10 \times 10 \times$ $10 \mathrm{~mm}$ ) up to $50 \%$ of their original height.

\section{Statistical analysis}

PCA as a multivariate analytical tool was used to reduce the set of original variables and to extract a small number of latent factors (principal components, PCs) in order to analyse the relationships among the variables studied and the classification of samples. The principal components are linear combinations of the original variables. The first PC is oriented to explain as much variation of the data as possible and it presents the best linear summary. The second PC is orthogonal to the first and it explains 
the next largest variance of the data, and so forth. The PCs were plotted in a threedimensional space to produce score plots. In the score plot the relationship between the samples was visualized, hence the samples close to each other in the score plot were similar. The number of PCs extracted from the variables was determined by a Kaiser's rule [17]. This criterion retains only factors with eigenvalues $>1$. A Wilcoxon signedrank test was used to estimate differences between the farmed and the wildlife red deer on a significance level of 0.05 . All the computational analyses, including the graphical representation, were performed using an XLSTAT 2014.5.03 (2014) software package.

\section{Results and discussion}

The first seven PCs satisfy the Kaiser's rule. Those seven PCs explain more than $90 \%$ of the total variance for the tested parameters. The first three PCs explain more than $62 \%$ of the total variance. The results of the PC analysis are presented in Tab. 1.

Table 1. Results of Principal Component Analysis

Tabela 1. Wyniki analizy składowych głównych

\begin{tabular}{||l|c|c|c|c|c|c|c||}
\hline \hline \multicolumn{1}{|c|}{ Item / Wyszczególnienie } & PC1 & PC2 & PC3 & PC4 & PC5 & PC6 & PC7 \\
\hline $\begin{array}{l}\text { Eigenvalue } \\
\text { Wartość własna }\end{array}$ & 7.64 & 4.57 & 3.47 & 2.73 & 1.72 & 1.47 & 1.07 \\
\hline $\begin{array}{l}\text { Variance } \\
\text { Zmiennóś [\%] }\end{array}$ & 30.57 & 18.29 & 13.88 & 10.94 & 6.89 & 5.90 & 4.29 \\
\hline $\begin{array}{l}\text { Cumulative value } \\
\text { Wartość skumulowana [\%] }\end{array}$ & 30.57 & 48.86 & 62.75 & 73.69 & 80.59 & 86.49 & 90.79 \\
\hline
\end{tabular}

Šnirc et al. [22] found that the first five PCs explained more than $85 \%$ of the total variance for $\mathrm{pH}$ and chemical \& technological parameters, whereas the level of total variance of the textural parameters of farmed and wildlife red deer was $86 \%$. Based on the analysed 76 morphometric parameters of the carcasses from the young Charolais bulls, Laville et al. [19] found that the first ten PCs explained $80 \%$ of the total variance of the parameters measured. However, as regards the rabbits, Hernández et al. [11] reported the first four PCs for the meat quality explained $62 \%$ of the total variance. They analyzed the meat quality using 23 variables including $\mathrm{pH}$, meat colour, WHC, cooking loss, fatty acid composition and sensory parameters. Cañeque et al. [4] analyzed the meat of light lambs and used 20 variables; they reported that the first five PCs explained $77 \%$ of the total variance. The eigenvalues and cumulative values are shown in Fig. 1.

Tab. 2 displays the p-value significance and all the variables. PC4, PC5, PC6, and PC7 data are not shown. As for the first PC, the most important variables are the chewiness, springiness and cohesiveness of the fried samples, the cooking loss of the water 


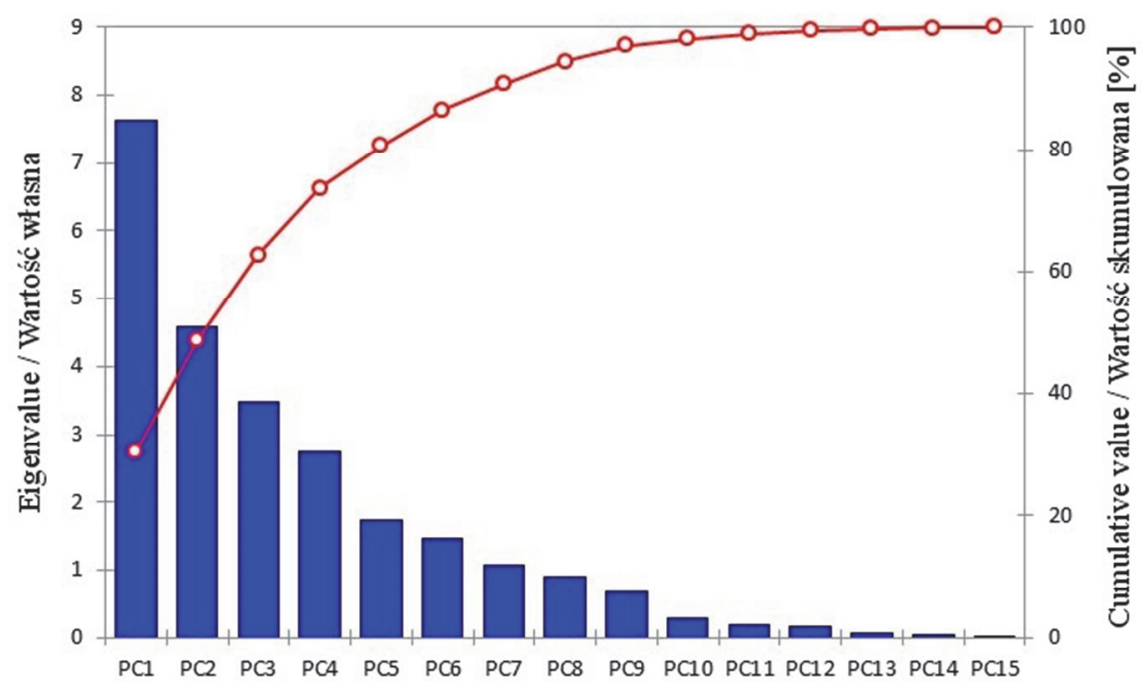

Fig. 1. Eigenvalues of matrices and cumulative values of variances of principal components

Rys. 1. Wartości własne macierzy i wartości skumulowane zmienności składowych głównych

bath samples and the content of fat and springiness of the cooked samples. The second PC is characterized by the water holding capacity and a content of protein. The third PC is defined by the hardness of the water bath samples, the shear force of the fried samples and the chewiness of the water bath samples. All the variables in Tab. 2 are visualized in a three-dimensional loading plot (Fig. 2). The ultimate $\mathrm{pH}$ and $\mathrm{WHC}$ are the factors to affect meat quality parameters such as tenderness, colour and juiciness $[29,14]$. The analysis of the meat showed significant differences $(\mathrm{p}<0.05)$ as regards $\mathrm{pH}$ and water holding capacity. Those data are inconsistent with the results by Hutchison who reported that the diet had no effect on the ultimate $\mathrm{pH}$ or thaw/loss purge [15].

In the case of the cooking loss, a significant difference between the two deer groups studied was reported only with regard to samples cooked in the water bath at $75{ }^{\circ} \mathrm{C}$.

The analysis of the basic chemical parameters showed significant differences in all the tested analytes (water, protein, and fat) except for ash where the p-value was 0.554. The chemical composition of different muscles of the farmed red deer indicated that in general the farmed red deer had higher contents of intramuscular fat compared to the free-range roe deer $[12,6]$. The results obtained in this study confirms these findings. Similar results were found in the comparative studies on the grain and pasture feeding systems for cattle [26] and deer [15]. Modern image analysis methods can be applied to thoroughly assess the quality of fat [5]. The study by Dannenberger et al. [7] 
also showed a high extent of variance of the macro- and micronutrients between the roe deer, which resulted from the varied environmental factors of free-range animals. With reference to red deer, the results obtained under the present research study correspond with those findings.

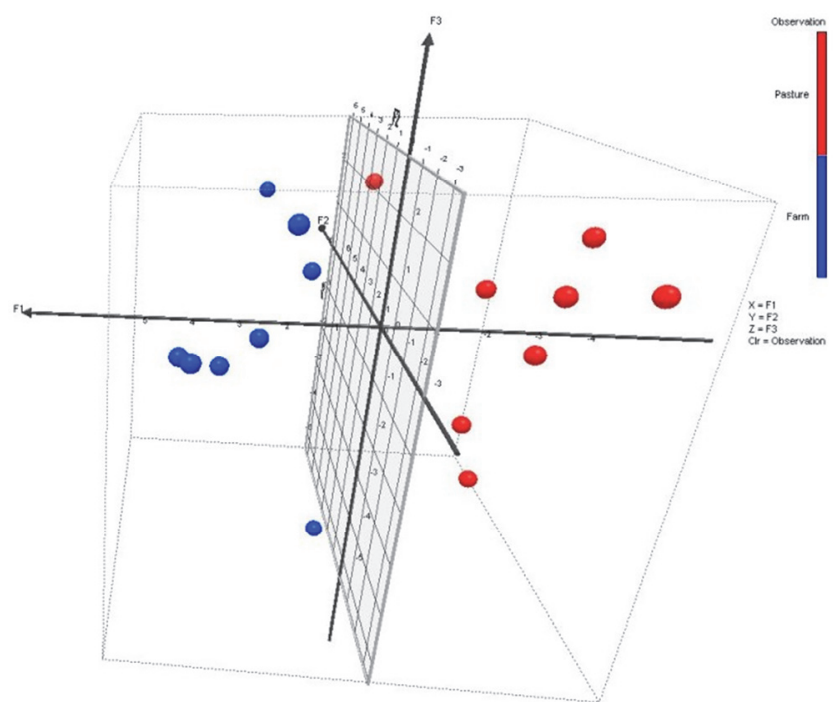

Fig. 2. 3D chart of the first three PCs loading vectors

Rys. 2. Wykres 3D wektorów kierunkowych trzech pierwszych składowych głównych

The shear force in the present study showed no significant difference between the two deer groups in any of the cooking procedures. This confirms the findings of Volpelli et al. [25] who reported no effect of the diet on the shear force. Kadim et al. [16] noted that the variance of the shear force might be due to differences between other important factors such as connective tissue structure, size of the muscle bundles, rigidity and water holding capacity.

According to Alfaig et al. [1], the texture is probably the only most critical quality factor associated with the ultimate consumer satisfaction. The raw meat is tough - the viscous flow in the fluid-filled channels between the fibres and fibre bundles; heating up to $65{ }^{\circ} \mathrm{C}$ increases tenderness - the sarcoplasmic proteins aggregate forming a gel and make it easier to fracture the meat using one's teeth [3], while heating over $65^{\circ} \mathrm{C}$ up to $80{ }^{\circ} \mathrm{C}$ makes the meat tougher - the elastic modulus increases and requires larger tensile stress to extend fractures [24]. 
Table 2. Variables: $\mathrm{pH}$, chemical, technological and textural parameters of Musculus semimembranosus from deer and their significance

Tabela 2. Zmienne: pH, parametry chemiczne, technologiczne i parametry tekstury Musculus semimembranosus jeleni i ich istotność

\begin{tabular}{|c|c|c|c|c|c|}
\hline Variables / Zmienne & $\mathrm{PC} 1$ & PC2 & $\mathrm{PC} 3$ & p-value & $\begin{array}{l}\text { Significance } \\
\text { Istotność }\end{array}$ \\
\hline $\mathrm{pH}$ & -0.13 & -0.72 & -0.13 & 0.030 & * \\
\hline WHC / Wodochłonność $\left[\mathrm{cm}^{2} / \mathrm{g}\right]$ & -0.17 & 0.92 & 0.15 & 0.030 & $*$ \\
\hline Drip loss / Wyciek swobodny [\%] & 0.04 & -0.83 & -0.07 & 0.529 & - \\
\hline $\begin{array}{l}\text { Cooking loss - water bath } \\
\text { Ubytek termiczny - gotowanie w wodzie }\left(75^{\circ} \mathrm{C}\right)\end{array}$ & 0.87 & 0.06 & -0.09 & 0.042 & $*$ \\
\hline $\begin{array}{l}\text { Cooking loss - roasting in oven } \\
\text { Ubytek termiczny - pieczenie }\left(190^{\circ} \mathrm{C}\right)\end{array}$ & 0.82 & -0.28 & -0.11 & 0.080 & - \\
\hline $\begin{array}{l}\text { Cooking loss - frying } \\
\text { Ubytek termiczny - smażenie }\left(80^{\circ} \mathrm{C}\right)\end{array}$ & -0.76 & 0.28 & 0.08 & 0.107 & - \\
\hline Water / Woda [\%] & -0.54 & 0.75 & 0.16 & 0.014 & $*$ \\
\hline Protein / Białko [\%] & 0.08 & 0.9 & 0.07 & 0.021 & $*$ \\
\hline Fat / Tłuszcz [\%] & 0.88 & 0.01 & -0.09 & 0.014 & * \\
\hline Ash / Popió1 [\%] & -0.12 & 0.11 & 0.18 & 0.554 & - \\
\hline $\begin{array}{l}\text { Water bath - shear force } \\
\text { Gotowanie w wodzie - siła cięcia }[\mathrm{kg}]\end{array}$ & -0.02 & 0.31 & 0.46 & 0.800 & - \\
\hline $\begin{array}{l}\text { Water bath - hardness } \\
\text { Gotowanie w wodzie - twardość }[\mathrm{N}]\end{array}$ & 0.14 & 0.07 & 0.77 & 0.294 & - \\
\hline $\begin{array}{l}\text { Water bath - cohesiveness } \\
\text { Gotowanie w wodzie - spójność [-] }\end{array}$ & 0.12 & -0.41 & 0.63 & 0.832 & - \\
\hline $\begin{array}{l}\text { Water bath - springiness } \\
\text { Gotowanie w wodzie - sprężystość [mm] }\end{array}$ & 0.84 & 0.15 & 0.34 & 0.014 & $*$ \\
\hline $\begin{array}{l}\text { Water bath - chewiness } \\
\text { Gotowanie w wodzie - żujność }[\mathrm{N} \cdot \mathrm{mm}]\end{array}$ & 0.66 & -0.07 & 0.64 & 0.107 & - \\
\hline Roasting - shear force / Pieczenie - siła cięcia [kg] & 0.33 & -0.08 & 0.48 & 0.673 & - \\
\hline Roasting - hardness / Pieczenie - twardość [N] & 0.71 & 0.34 & -0.09 & 0.021 & * \\
\hline Roasting - cohesiveness / Pieczenie - spójność [-] & 0.44 & 0.06 & -0.19 & 0.416 & - \\
\hline $\begin{array}{l}\text { Roasting - springiness } \\
\text { Pieczenie - sprężystość [mm] }\end{array}$ & 0.07 & 0.38 & -0.65 & 0.572 & - \\
\hline Roasting - chewiness / Pieczenie - żujność [N·mm] & 0.47 & 0.29 & -0.44 & 0.141 & - \\
\hline Frying - shear force / Smażenie - siła cięcia $[\mathrm{kg}]$ & 0.35 & -0.04 & 0.65 & 0.363 & - \\
\hline Frying - hardness / Smażenie - twardość [N] & 0.2 & 0.42 & 0.33 & 0.834 & - \\
\hline Frying - cohesiveness / Smażenie - spójnośc [-] & 0.76 & 0.29 & -0.37 & 0.014 & * \\
\hline Frying - springiness / Smażenie - sprężystość [mm] & 0.85 & -0.11 & -0.08 & 0.014 & $*$ \\
\hline Frying - chewiness / Smażenie - żujność [N·mm] & 0.9 & 0.21 & -0.18 & 0.014 & * \\
\hline
\end{tabular}

Explanatory notes / Objaśnienia:

* - significance of differences between mean values of parameters of Musculus semimembranosus from farmed and wildlife deer $(\mathrm{p}<0.05)$ / istotność różnic pomiędzy wartościami średnimi parametrów Musculus semimembranosus jeleni hodowlanych i dziko żyjących $(\mathrm{p}<0,05)$.

The texture profile analysis performed after water bath showed a significant difference $(\mathrm{p}<0.05)$ only in the springiness. Among all the cooking procedures studied, 
the difference in the hardness was reported only in the case of the roasting in the oven. Significant differences on a level of $p=0.014$ were found in the cohesiveness, springiness and chewiness of the fried meat samples. Laakkonen et al. [18] claim that changes in the meat tenderness during cooking are associated with the heat-induced alteration of myofibrillar proteins and connective tissue since the heat solubilises the connective tissue and this leads to meat tenderization, while the denaturation of myofibrillar proteins causes the meat to toughen. Considering the possible adulteration of meat and meat products [20], there is a need to develop highly sensitive and accurate procedures to detect it.

\section{Conclusions}

1. On the basis of the overall results of various analyses, PCA proved to be a very useful method to identify the most effective variables and to quickly point out the relationships among the variables themselves.

2. It was possible to distinguish between the Musculus semimembranosus meat samples derived from the farmed and wildlife groups of red deer by indicating differences in the meat characteristics.

3. The principal component analysis showed that the meat samples from the wildlife and farmed groups of red deer were differentiated by PC1, PC2 and PC3.

4. The explained variance of the first three PCs was $62.75 \%$. The results obtained in this study suggest that the $\mathrm{pH}$-value, chemical, technological and textural properties have a good potential for predicting the origin of meat.

\section{References}

[1] Alfaig E., Angelovicova M., Kral M., Vietoris V., Zidek R.: Effect of probiotics and thyme essential oil on the texture of cooked chicken breast meat. Acta Sci. Pol. Technol. Aliment., 2013, 12 (4), 379-384.

[2] AOAC: Official Methods of Analysis. $18^{\text {th }}$ ed. Association of Official Analytical Chemists International, Gaithersburg 2006.

[3] Baldwin D.E.: Sous vide cooking: A review. Int. J. Gastron. Food Sci., 2012, 1 (1), 15-30.

[4] Cañeque V., Pérez C., Velasco S., Lauzurica S., Alvarez I.: Carcass and meat quality of light lambs using principal component analysis. Meat Sci., 2004, 67 (4), 595-605.

[5] Č́slavková P., Pospiech M., Štarha P., Kameník J., Saláková A., Tremlová B., Řezáčová Lukášková Z.: Verwendung der Bildanalyse für die Bewertung des Anschnitts der Rohwurstsorte Poličan. Fleischwirtschaft, 2014, 94, 88-93.

[6] Dahlan I., Norfarizan Hanoon N.: Chemical composition, palatability and physical characteristics of venison from farmed deer. Anim. Sci. J., 2008, 79 (4), 498-503.

[7] Dannenberger D., Nuernberg G., Nuernberg K., Hagemann E.: The effects of gender, age and region on macro- and micronutrient contents and fatty acid profiles in the muscles of roe deer and wild boar in Mecklenburg-Western Pomerania (Germany). Meat Sci., 2013, 94 (1), 39-46. 
[8] Drew K.R., Seman D.L.: The nutrient content of venison. Proceedings of the Nutrition Society of New Zealand, Mosgiel, 1987, 12, 49-55.

[9] Guerrero L., Gou P., Alonso P., Arnau J.: Study of the physicochemical and sensorial characteristics of dry-cured hams in three pig genetic types. J. Sci. Food Agric., 1996, 70 (4), 526-530.

[10] Hamm R.: Functional Properties of the Myofibrillar System and Their Measurements. Academic Press, New York City, New York, 1986, pp. 135-192.

[11] Hernández P., Pla M., Oliver M.A., Blasco A.: Relationships between meat quality measurements in rabbits fed with three diets of different fat type and content. Meat Sci., 2000, 55 (4), 379-384.

[12] Hoffman L.C., Wiklund E.: Game and venison - meat for the modern consumer. Meat Sci., 2006, 74 (1), 197-208

[13] Honikel K.O.: Reference methods for the assessment of physical characteristics of meat. Meat Sci., 1998, 49 (4), 447-457.

[14] Hopkins D.L., Ashton-Jones S., Bouton P., Harris P., Shorthose W., Baxter R.: Processing technology changes in the Australian sheep meat industry: An overview. Anim. Prod. Sci., 2011, 51 (5), 399405.

[15] Hutchison C.L., Mulley R.C., Wiklund E., Flesch J.S.: Effect of concentrate feeding on instrumental meat quality and sensory characteristics of fallow deer venison. Meat Sci., 2012, 90 (3), 801-806.

[16] Kadim I.T., Al-Karousi A., Mahgoub O., Al-Marzooqi W., Khalaf S.K., Al-Maqbali R.S.: Chemical composition, quality and histochemical characteristics of individual dromedary camel (Camelus dromedarius) muscles. Meat Sci. 2013, 93 (3), 564-571.

[17] Kaiser H.F., Rice J.: Little jiffy, mark IV. Educational and psychological measurement, 1974, 34 (1), 111-117.

[18] Laakkonen E., Wellington G., Sherbon J.: Low-temperature, long-time heating of bovine muscle 1. Changes in tenderness, water-binding capacity, $\mathrm{pH}$ and amount of water-soluble components. J. Food Sci., 1970, 35 (2), 175-177.

[19] Laville E., Martin V., Bastien O.: Prediction of composition traits of young Charolais bull carcasses using a morphometric method. Meat Sci., 1996, 44 (1-2), 93-104.

[20] Randulová Z., Tremlová B., Rezacova Lukaskova Z., Pospiech M., Straka I.: Determination of soya protein in model meat products using image analysis. Czech J. Food Sci., 2011, 29 (4), 318-321.

[21] Regulation (EC) No 854/2004 of the European Parliament and of the Council of 29 April 2004 of laying down specific rules for the organisation of official controls on products of animal origin intended for human consumption. OJ L 139, pp. 206-320, of 30.04. 2004.

[22] Šnirc M., Král M., Ošt'ádalová M., Golian J., Tremlová B.: Application of principal component analysis method for characterization chemical, technological, and textural parameters of farmed and pastured red deer. Int. J. Food Prop., 2016, 20 (4), 754-761.

[23] Szczesniak A.S.: Texture is a sensory property. Food Qual. Prefer., 2002, 13 (4), 215-225.

[24] Tornberg E.: Effects of heat on meat proteins - Implications on structure and quality of meat products. Meat Sci., 2005, 70 (3), 493-508.

[25] Volpelli L.A., Valusso R., Morgante M., Pittia P., Piasentier E.: Meat quality in male fallow deer (Dama dama): Effects of age and supplementary feeding. Meat Sci., 2003, 65 (1), 555-562.

[26] Walstra P.: Dairy technology: Principles of Milk Properties and Processes. CRC Press, Boca Raton 1999, p. 727.

[27] Wiklund E., Johansson L., Malmfors G.: Sensory meat quality, ultimate pH values, blood parameters and carcass characteristics in reindeer (Rangifer tarandus tarandus $L$.) grazed on natural pastures or fed a commercial feed mixture. Food Qual. Prefer., 2003, 14 (7), 573-581.

[28] Wiklund E., Malmfors G., Lundström K., Rehbinder C.: Pre-slaughter handling of reindeer bulls (Rangifer tarandus tarandus L.) - effects on technological and sensory meat quality, blood metabolites and muscular and abomasal lesions. Rangifer, 1996, 16 (3), 109-117. 
[29] Wiklund E., Manley T.R., Littlejohn R.P., Stevenson-Barry J.M.: Fatty acid composition and sensory quality of Musculus longissimus and carcass parameters in red deer (Cervus elaphus) grazed on natural pasture or fed a commercial feed mixture. J. Sci. Food Agric., 2003, 83 (5), 419-424.

[30] Żochowska J., Lachowicz K., Gajowiecki L., Sobczak M., Kotowicz M., Żych A.: Effects of carcass weight and muscle on texture, structure and myofibre characteristics of wild boar meat. Meat Sci., 2005, 71 (2), 244-248.

\title{
RÓŻNICE POMIĘDZY PARAMETRAMI TECHNOLOGICZNYMI I TEKSTURALNYMI MIĘSA JELENI (CERVUS ELAPHUS) HODOWLANYCH I DZIKO ŻYJĄCYCH OKREŚLONE METODĄ SKLADOWYCH GLÓWNYCH
}

\author{
Streszczenie
}

Ostatnio obserwuje się tendencję wzrostową spożycia dziczyzny, zwłaszcza mięsa jeleni, z uwagi na jej wartość odżywczą i specyficzny smak. Chemiczne, technologiczne i teksturalne właściwości mięsa należą do jego podstawowych wyróżników jakości. Na preferencje konsumentów silnie wpływają sposoby obróbki termicznej, jakim zostało poddane mięso, a które wpływają na jego smakowitość zmieniającą się wraz ze zmianami tekstury i właściwości chemicznych.

Celem pracy było określenie jakości mięsa jeleni szlachetnych (Cervus elaphus) i różnic pomiędzy parametrami technologicznymi i teksturalnymi mięsa zwierząt hodowlanych i dziko żyjących. Próbki pobierano z mięśnia Musculus semimembranosus (półbłoniastego). Do analizy zastosowano metodę składowych głównych (PCA). Pierwsze siedem składowych głównych wyjaśniało (opisywało) więcej niż 90 \% całkowitej zmienności badanych parametrów, przy czym trzy pierwsze składowe główne opisywały więcej niż $62 \%$ całkowitej zmienności analizowanych parametrów. Żujność, sprężystość i spójność smażonych próbek, ubytek cieplny w trakcie gotowania w wodzie, zawartość tłuszczu oraz sprężystość próbek gotowanych były najistotniejszymi zmiennymi w przypadku pierwszej składowej głównej. Statystycznie istotne różnice $(\mathrm{p}<0,05)$ dotyczyły zawartości wody, białka i thuszczu. Analiza profilu tekstury mięsa wykazała istotne $(\mathrm{p}<0,05)$ różnice pod względem: sprężystości w próbce poddanej gotowaniu w wodzie, twardości i spójności w próbce poddanej pieczeniu oraz spójności, sprężystości i żujności w próbce smażonej. Na podstawie uzyskanych wyników badań stwierdzono, że pH, oraz parametry chemiczne, technologiczne i teksturalne mogą dostarczyć użytecznych informacji pozwalających na ustalenie pochodzenia mięsa (zwierzęta hodowlane vs. zwierzęta dziko żyjące).

Słowa kluczowe: Musculus semimembranosus, jeleń szlachetny, mięso, sposoby obróbki termicznej, jakość, metoda składowych głównych (PCA) 